\title{
Pengaruh Pelatihan dan Motivasi terhadap Produktivitas Kerja Karyawan pada PT. Lion Mentari Airlines Bandara Internasional Soekarno Hatta Cengkareng
}

\author{
${ }^{1}$ Sarwani*, ${ }^{2}$ Irfan Rizka Akbar, ${ }^{3}$ Agus Leo Handoko, ${ }^{4}$ Hadion Wijoyo \\ 1,2,Universitas Pamulang ${ }^{3,4}$ STAB Dharma Widya \\ Alamat Surat Email: ${ }^{1}$ dosen00005@ unpam.ac.id, ${ }^{2}$ dosen02461@unpam.ac.id, \\ 3agus_leo@stabdharmawidya.ac.id, \\ 4hadion.wijoyo@lecturer.stmikdharmapalariau.ac.id
}

\begin{abstract}
Article History:
Received: 10-Nopember-2020; Received in Revised: 25-Nopember-2020; Accepted: 30-Nopember-2020
\end{abstract}

\begin{abstract}
ABSTRAK
Penelitian ini bertujuan untuk mengetahui pengaruh pelatihan dan motivasi terhadap produktiivitas kerja karyawan pada PT. Lion Mentari Airlines Bandara Internasional Soekarno Hatta Cengkareng. Metode yang digunakan adalah explanatory research dengan teknik analisis menggunakan analisis statistik dengan pengujian regresi, korelasi, determinasi dan uji hipotesis. Hasil penelitian ini pelatihan berpengaruh signifikan terhadap produktiivitas kerja karyawan sebesar $37,8 \%$, uji hipotesis diperoleh $\mathrm{t}$ hitung $>\mathrm{t}$ tabel atau $(6,184>1,998)$. Motivasi berpengaruh signifikan terhadap produktiivitas kerja karyawan sebesar 51,6\%, uji hipotesis diperoleh $t$ hitung $>t$ tabel atau $(8,199>$ 1,998). Pelatihan dan motivasi secara simultan berpengaruh signifikan terhadap produktiivitas kerja karyawan dengan persamaan regresi $\mathrm{Y}=6,954+0,307 \mathrm{X} 1+0,530 \mathrm{X} 2$ dan kontribusi pengaruh sebesar $60,4 \%$, uji hipotesis diperoleh F hitung > F tabel atau (47,275 > 2,750).
\end{abstract}

Kata kunci: Pelatihan, Motivasi, Produktiivitas kerja karyawan

\section{ABSTRACT}

This study aims to determine the effect of training and motivation on employee productivity at PT. Lion Mentari Airlines Soekarno Hatta International Airport, Cengkareng. The method used is explanatory research with analysis techniques using statistical analysis with regression testing, correlation, determination and hypothesis testing. The results of this research training have a significant effect on employee work productivity by 37.8\%; hypothesis testing is obtained $t$ count $>t$ table or (6.184> 1.998). Motivation has a significant effect on employee work productivity by 51.6\%; hypothesis testing is obtained $t$ count $>t$ table or $(8,199>1,998)$. Training and motivation simultaneously have a significant effect on employee work productivity with the regression equation $Y=6.954+0.307 X 1+0.530 X 2$ and the contribution of the effect is $60.4 \%$, the hypothesis test obtained $F$ count $>F$ table or $(47.275>2.750)$. 


\section{Keywords: Training, Motivation, Employee productivity}

\section{PENDAHULUAN}

Suatu perusahaan dalam melaksanakan kegiatannya, baik perusahaan yang bergerak dibidang industri, perdagangan maupun jasa akan berusaha untuk mencapai tujuan yang telah ditetapkan sebelumnya. Satu hal yang penting yaitu bahwa keberhasilan berbagai aktivitas didalam perusahaan dalam mencapai tujuan bukan hanya tergantung pada keunggulan teknologi, dana operasi yang tersedia, sarana ataupun prasarana yang dimiliki, melainkan juga tergantung pada aspek sumber daya manusia. Faktor sumber daya manusia ini merupakan elemen yang harus diperhatikan oleh perusahaan, terutama bila mengingat bahwa era perdagangan bebas akan segera dimulai, dimana iklim kompetisi yang dihadapi akan sangat berbeda. Hal ini memaksa setiap perusahaan harus dapat bekerja dengan lebih efisien, efektif dan produktif. Tingkat kompetisi yang tinggi akan memacu tiap perusahaan untuk dapat mempertahankan kelangsungan hidupnya dengan memberikan perhatian pada aspek sumber daya manusia. Jadi manusia dapat dipandang sebagai faktor penentu karena ditangan manusialah segala inovasi akan direalisir dalam upaya mewujudkan tujuan perusahaan.

Di Negara Indonesia Transportasi berkembang seiring dengan perkembangan jaman. Sarana transportasi di Indonesia berguna sebagai sarana penghubung antar daerah yang tersebar dari Sabang sampai Merauke.

Transportasi udara merupakan transporasi yang sangat efektif dan efisien dalam proses pergerakan manusia/barang karena transportasi udara memiliki system yang cepat dan dapat mencapai area yang sulit dijangkau. Perkembangan transportasi udara atau yang kita sebut penerbangan udara di Indonesia mengalami perkembangan yang cukup singnifikan dilihat dari besarnya potensi jumlah penumpang dan banyaknya maskapai penerbangan yang ada. Sebagian besar maskapai penerbangan yang ada menerapkan sistem LCC (low cost carrier) yakni biaya opreasional yang kecil dimana maskapai penerbangan memangkas biaya operasional yang dikeluarkan dan melakukan efisiensi.

Menjamurnya maskapai penerbangan bertarif murah di Indonesia dimulai sejak dibukanya deregulasi penerbangan niaga oleh pemerintah pada tahun 2001. Aturan baru itu memberikan kesempatan kepada para pengusaha untuk menjalankan jasa penerbangan meski dengan hanya memiliki satu pesawat dan modal cekak. Kesempatan itu dikuatkan dengan tidak adanya aturan mengenai batas tarif bawah yang membuat perusahan-perusahaan penerbangan berlomba memasang tarif rendah untuk memikat penumpang.

PT Lion Mentari Airlines yang memiliki nama brand penerbangan Lion Air adalah salah satu perusahaan yang menerapkan sistem LCC (low cost carrier) dimana maskapai tersebut menawarkan tarif murah dengan menekan sejumlah biaya, termasuk biaya operasional, seperti gaji karyawan, katering, hingga sistem penjualan tiket. Harga murah inilah yang menjadi alasan mereka diminati penumpang.

Dengan menerapkan sistem LCC (low cost carrier) bukan berarti Lion Air mengesampingkan pelayanan ataupun keamanan penerbangan, tetapi terus memajukan pelayanan sesuai Peraturan Menteri Perhubungan NO 185 Tahun 2015 tentang (Standar pelayanan penumpang kelas ekonomi angkatan udara niaga berjadwal dalam negeri) dan keamanan sesuai dengan Peraturan Menteri Perhubungan NO 31 tahun 2013 tentang (Program keamanan nasional) dan UU RI NO 1 tahun 2009 tentang (penerbangan).

Untuk meningkatkan pelayanan dan keamanan maka diperlukan pengelolaan sumber daya manusia dengan baik, Pengelolaan sumber daya manusia yang dimaksud adalah perusahaan harus mampu untuk menyatukan cara pandang karyawan dan pimpinan perusahaan dalam rangka mencapai tujuan perusahaan. Salah satu cara yang umum dilakukan perusahaan adalah melalui pelatihan. 
Pelatihan akan memberikan kesempatan karyawan mengembangkan keahlian dan kemampuan dalam bekerja dan untuk menambah pengetahuan. Tenaga kerja merupakan salah satu faktor penting yang harus diperhatikan oleh perusahaan dalam rangka mencapai tujuannya.

Menurut Andrew E. Sikula yang dikutip oleh Anwar Prabu Mangkunegara (2013:44) mengemukakan bahwa pelatihan (training) adalah "suatu proses pendidikan jangka pendek yang mempergunakan prosedur sistematis dan terorganisasi, karyawan non manajerial mempelajari pengetahuan dan keterampilan teknis dalam tujuan yang terbatas". Berikut adalah data pelatihan yang diberikan perusahaan PT Lion Mentari Airlines kepada karyawan di Bandara Soekarno Hatta Cengkareng untuk tercapainya tujuan perusahaan.

Selain pelatihan, hal yang terpenting bagi karyawan untuk meningkatan pelayanan adalah motivasi. Motivasi untuk bekerja sangat penting bagi tinggi rendahnya produktivitas perusahaan. Tanpa adanya motivasi dari para karyawan untuk bekerja sama bagi kepentingan perusahaan, maka tujuan yang telah ditetapkan tidak akan tercapai. Sebaliknya apabila terdapat motivasi yang tinggi dari para karyawan, maka hal ini merupakan suatu jaminan atas keberhasilan perusahaan dalam mencapai tujuan. Menurut pendapat Anwar Prabu Mangkunegara (2013:93) motif adalah suatu dorongan kebutuhan dalam diri karyawan yang perlu di penuhi agar karyawan tersebut dapat menyesuaikan diri terhadap lingkungannya, sedangkan motivasi adalah kondisi yang menggerakan karyawan agar mampu mencapai tujuan dari motifnya. Definisi produktivitas menurut Sedamayanti (2009:58) pengertian produktivitas memiliki dua dimensi yakni efektivitas dan efesiensi. Dimensi pertama berkaitan dengan pencapaian untuk kerja yang maksimal, dalam arti pencapaian target yang berkaitan dengan kualitas, kuantitas, dan waktu. Sedangkan dimensi yang kedua berkaitan dengan upaya membandingkan masukan dengan realisasi penggunaannya atau bagaimana pekerjaan tersebut dilaksanakan.

Peningkatan produktivitas merupakan masalah sistem dalam arti tertentu, karena ada banyak segi dari pekerjaan dan kegiatan perusahaan yang mempunyai dampak terhadap peningkatan produktivitas tenaga kerja. Bidang kerja yang dapat meningkatkan produktivitas di samping perlunya pembenahan kembali beberapa bagian organisasi dan fungsi karyawan untuk menunjang peningkatan produktivitas semaksimal mungkin. Dalam setiap perusahaan tentu masalah seperti menurunnya produktivitas kerja karyawan pasti terjadi, begitu juga yang dialami perusahaan penerbangan PT Lion Mentari Airlines Bandara Soekarno Hatta Cengkareng dimana masih banyak karyawan yang tidak bekerja sesuai dengan standar prosedur yang sudah di tetapkan baik dari segi pelayanan maupun keamanan.

Tabel 1. Data Produktivitas Karyawan PT Lion Mentari Airlines Bandara Soekarno Hatta Cengkareng Periode Tahun 2019

\begin{tabular}{|l|c|c|c|c|c|c|}
\hline \multicolumn{1}{|c|}{ Bulan } & Flight Delay & $\begin{array}{c}\text { Flight } \\
\text { Ontime }\end{array}$ & Total Flight & $\begin{array}{c}\text { Flight } \\
\text { Delay (\%) }\end{array}$ & $\begin{array}{c}\text { Flight } \\
\text { Ontime (\%) }\end{array}$ & Target (\%) \\
\hline Jan & 2163 & 3271 & 5434 & $40 \%$ & $60 \%$ & $80 \%$ \\
\hline Feb & 1737 & 2852 & 4589 & $38 \%$ & $62 \%$ & $80 \%$ \\
\hline Mar & 1410 & 3716 & 5126 & $28 \%$ & $72 \%$ & $80 \%$ \\
\hline Apr & 1298 & 3621 & 4919 & $26 \%$ & $74 \%$ & $80 \%$ \\
\hline May & 1157 & 3611 & 4768 & $24 \%$ & $76 \%$ & $80 \%$ \\
\hline Jun & 693 & 3719 & 4412 & $16 \%$ & $84 \%$ & $80 \%$ \\
\hline Jul & 1659 & 3929 & 5588 & $30 \%$ & $70 \%$ & $80 \%$ \\
\hline Aug & 940 & 4060 & 5000 & $19 \%$ & $81 \%$ & $80 \%$ \\
\hline Sep & 557 & 4419 & 4976 & $11 \%$ & $89 \%$ & $80 \%$ \\
\hline
\end{tabular}




\begin{tabular}{|l|c|c|c|c|c|c|}
\hline Oct & 846 & 4362 & 5208 & $16 \%$ & $84 \%$ & $80 \%$ \\
\hline Nov & 871 & 4261 & 5132 & $17 \%$ & $83 \%$ & $80 \%$ \\
\hline Dec & 1463 & 3915 & 5378 & $27 \%$ & $73 \%$ & $80 \%$ \\
\hline Total & 14794 & 45736 & 60530 & $24 \%$ & $76 \%$ & $80 \%$ \\
\hline
\end{tabular}

Sumber: HRD PT Lion Mentari Airlines

Berdasarkan latar belakang di atas penulis tertarik untuk meneliti tentang Pengaruh Pelatihan dan Motivasi Terhadap Produktivitas Kerja Karyawan pada perusahaan PT Lion Mentari Airlines, dengan memilih judul sebagai berikut: "Pengaruh Pelatihan dan Motivasi Terhadap Produktivitas Kerja Karyawan PT Lion Mentari Airlines Bandara Internasional Soekarno Hatta Cengkareng“.

\subsection{Kajian Pustaka \\ Pelatihan}

Yang dimaksud dengan pelatihan adalah suatu proses pendidikan jangka pendek yang mempergunakan prosedur sistematis dan terorganisasi. Pelatihan dibatasi tentang keahlian dan pengetahuan karyawan selama bekerja dalam perusahaan tersebut.

\section{Motivasi}

Yang dimaksud dengan motivasi keseluruhan proses pemberian motif bekerja kepada para bawahan sedemikian rupa sehingga mereka mau bekerja dengan ikhlas demi tercapainya tujuan organisasi dengan efisien dan ekonomis. Dalam hal motivasi penulis membatasi mengenai berbagai macam dorongan kerja yang timbul baik dalam maupun dari luar seseorang untuk berperilaku dalam mencapai tujuan.

\section{Produktivitas kerja karyawan}

Yang dimaksud dengan produktivitas kinerja karyawan adalah produktivitas memiliki dua dimensi yakni efektivitas dan efesiensi. Dimensi pertama berkaitan dengan pencapaian untuk kerja yang maksimal, dalam arti pencapaian target yang berkaitan dengan kualitas, kuantitas, dan waktu. Sedangkan dimensi yang kedua berkaitan dengan upaya membandingkan masukan dengan realisasi penggunaannya atau bagaimana pekerjaan tersebut dilaksanakan. Dalam produktivitas kerja karyawan penulis membatasi tentang keterkaitan hasil kerja karyawan dengan suatu waktu yang dibutuhkan untuk menghasilkan produk dari seorang karyawan.

\section{METODE Populasi}

Populasi dalam penelitian ini berjumlah 65 responden PT. Lion Mentari Airlines Bandara Internasional Soekarno Hatta Cengkareng Sampel

Sampel dalam penelitian ini berjumlah 65 responden.

\section{Jenis Penelitian}

Jenis penelitian yang dipakai adalah asosiatif, dimana tujuannya adalah untuk mengetahui pengaruh antara variabel bebas terhadap variabel terikat baik parsial maupun simultan

\section{Metode Analisis Data}

Dalam menganalisis data digunakan uji instrumen, uji asumsi klasik, regresi, koefisien determinasi dan uji hipotesis.

\section{HASIL DAN PEMBAHASAN}

\subsection{Hasil}




\section{Analisis Deskriptif}

Pada pengujian ini digunakan untuk mengetahui skor minimum dan maksimum, mean score dan standar deviasi dari masing-masing variabel. Adapun hasilnya sebagai berikut:

\section{Tabel Hasil Analisis Descriptive Statistics}

Descriptive Statistics

\begin{tabular}{|c|c|c|c|c|c|}
\hline & $\mathrm{N}$ & Minimum & Maximum & Mean & $\begin{array}{l}\text { Std. } \\
\text { ation }\end{array}$ \\
\hline Pelatihan (X1) & 65 & 31 & 48 & 37.65 & 3.850 \\
\hline Motivasi (X2) & 65 & 31 & 48 & 38.65 & 3.577 \\
\hline $\begin{array}{l}\text { Produktiivitas kerja } \\
\text { karyawan }(\mathrm{Y})\end{array}$ & 65 & 32 & 47 & 38.98 & 3.457 \\
\hline Valid N (listwise) & 65 & & & & \\
\hline
\end{tabular}

Pelatihan diperoleh varians minimum sebesar 31 dan varians maximum 48 dengan mean score sebesar 3,76 dengan standar deviasi 3,850. Motivasi diperoleh varians minimum sebesar 31 dan varians maximum 48 dengan mean score sebesar 3,86 dengan standar deviasi 3,577. Produktiivitas kerja karyawan diperoleh varians minimum sebesar 32 dan varians maximum 47 dengan mean score sebesar 3,89 dengan standar deviasi 3,457.

\section{Analisis Verifikatif.}

Pada analisis ini dimaksudkan untuk mengetahui pengaruh variabel independen terhadap variabel dependen. Adapun hasil pengujian sebagai berikut:

\section{Analisis Regresi Linier Berganda}

Uji regresi ini dimaksudkan untuk mengetahui perubahan variabel dependen jika variabel independen mengalami perubahan. Adapun hasil pengujiannya sebagai berikut:

Tabel Hasil Pengujian Regresi Linier Berganda

Coefficientsa

$$
\begin{array}{c|r}
\begin{array}{c}
\text { Unstandardized } \\
\text { Coefficients }
\end{array} & \begin{array}{c}
\text { Standardized } \\
\text { Coefficients }
\end{array}
\end{array}
$$

\begin{tabular}{|c|c|c|c|c|c|c|}
\hline \multicolumn{2}{|c|}{ Model } & $\mathrm{B}$ & $\begin{array}{l}\text { Std. } \\
\text { Error }\end{array}$ & Beta & \multirow{2}{*}{$\frac{\mathrm{t}}{2.101}$} & \multirow{2}{*}{$\frac{\text { Sig. }}{.040}$} \\
\hline 1 & (Constant) & 6.954 & 3.30 & & & \\
\hline & Pelatihan (X1) & .307 & .083 & .342 & 3.707 & .000 \\
\hline & Motivasi (X2) & .530 & .089 & .548 & 5.951 & .000 \\
\hline
\end{tabular}

a. Dependent Variable: Produktiivitas kerja karyawan (Y)

Berdasarkan hasil pengujian pada tabel di atas, diperoleh persamaan regresi $\mathrm{Y}=6,954+0,307 \mathrm{X} 1+$ 0,530X2. Dari persamaan tersebut dijelaskan sebagai berikut:

Konstanta sebesar 6,954 diartikan jika pelatihan dan motivasi tidak ada, maka telah terdapat nilai produktiivitas kerja karyawan sebesar 6,954 point. 
Koefisien regresi pelatihan sebesar 0,307 , angka ini positif artinya setiap ada peningkatan pelatihan sebesar 0,307 maka produktiivitas kerja karyawan juga akan mengalami peningkatan sebesar 0,307 point.

Koefisien regresi motivasi sebesar 0,530 , angka ini positif artinya setiap ada peningkatan motivasi sebesar 0,530 maka produktiivitas kerja karyawan juga akan mengalami peningkatan sebesar 0,530 point.

\section{Analisis Koefisien Korelasi}

Analisis koefisien korelasi dimaksudkan untuk mengetahui tingkt kekuatan hubungan dari variabel independen terhadap variabel dependen baik secara parsial maupun simultan. Adapun hasil pengujian sebagai berikut:

Tabel Hasil Pengujian Koefisien Korelasi Pelatihan Terhadap Produktiivitas kerja karyawan.

Correlationsb

\begin{tabular}{ccll|c} 
& & & Pelatihan & \multicolumn{1}{c}{$\begin{array}{c}\text { Produktiivitas } \\
\text { kerja karyawan (Y) }\end{array}$} \\
\hline Pelatihan $(\mathrm{X} 1)$ & & Pearson Correlation & 1 & $.615^{* *}$ \\
\hline & & Sig. (2-tailed) & .000 \\
\hline $\begin{array}{c}\text { Produktiivitas } \\
\text { karyawan }(\mathrm{Y})\end{array}$ & kerja & Pearson Correlation & $.615^{* *}$ & 1 \\
\cline { 3 - 5 } & & Sig. (2-tailed) & .000 & \\
\hline
\end{tabular}

Berdasarkan hasil pengujian diperoleh nilai korelasi sebesar 0,615 artinya pelatihan memiliki hubungan yang kuat terhadap produktiivitas kerja karyawan.

Tabel Hasil Pengujian Koefisien Korelasi Motivasi Terhadap Produktiivitas kerja karyawan.

Correlationsb

\begin{tabular}{ccccc} 
& & & Motivasi & \multicolumn{1}{c}{$\begin{array}{c}\text { Produktiivitas } \\
\text { kerja karyawan (Y) }\end{array}$} \\
\hline Motivasi (X2) & & Pearson Correlation & 1 & $.718^{* *}$ \\
\cline { 3 - 5 } & & Sig. (2-tailed) & .000 \\
\hline $\begin{array}{c}\text { Produktiivitas } \\
\text { karyawan (Y) }\end{array}$ & kerja & Pearson Correlation & $.718^{* *}$ & 1 \\
\cline { 3 - 5 } & & Sig. (2-tailed) & .000 & \\
\hline
\end{tabular}

Berdasarkan hasil pengujian diperoleh nilai korelasi sebesar 0,718 artinya motivasi memiliki hubungan yang kuat terhadap produktiivitas kerja karyawan.

Tabel Hasil Pengujian Koefisien Korelasi Pelatihan dan Motivasi secara simultan Terhadap Produktiivitas kerja karyawan.

Model Summary

Adjusted R Std. Error of the

\begin{tabular}{l|l|l|l} 
Model R & R Square Square & Estimate
\end{tabular} 


\begin{tabular}{|c|c|c|c|c|}
\hline 1 & $.777 \mathrm{a}$ & .604 & .591 & 2.211 \\
\hline
\end{tabular}

a. Predictors: (Constant), Motivasi (X2), Pelatihan (X1)

Berdasarkan hasil pengujian diperoleh nilai korelasi sebesar 0,777 artinya pelatihan dan motivasi secara simultan memiliki hubungan yang kuat terhadap produktiivitas kerja karyawan.

\section{Analisis Koefisien Determinasi}

Analisis koefisien determinasi dimaksudkan untuk mengetahui besarnya persentase pengaruh dari variabel independen terhadap variabel dependen baik secara parsial maupun simultan. Adapun hasil pengujian sebagai berikut:

Tabel Hasil Pengujian Koefisien Determinasi Pelatihan Terhadap Produktiivitas kerja karyawan.

Model Summary

\begin{tabular}{ll|ccc} 
Model & $\mathrm{R}$ & R Square & Square & $\begin{array}{c}\text { Adjusted } \\
\mathrm{R} \\
\text { Estimate }\end{array}$ \\
\hline 1 & $.615 \mathrm{a}$ & .378 & .368 & 2.749 \\
\hline
\end{tabular}

a. Predictors: (Constant), Pelatihan (X1)

Berdasarkan hasil pengujian diperoleh nilai determinasi sebesar 0,378 artinya pelatihan memiliki kontribusi pengaruh sebesar $37,8 \%$ terhadap produktiivitas kerja karyawan.

Tabel 7. Hasil Pengujian Koefisien Determinasi Motivasi Terhadap Produktiivitas kerja karyawan.

Model Summary

\begin{tabular}{ll|lcc} 
Model & $\mathrm{R}$ & R Square & Square & $\begin{array}{c}\text { Adjusted } \\
\text { Std. Error of the } \\
\text { Estimate }\end{array}$ \\
\hline 1 & $.718 \mathrm{a}$ & .516 & .509 & 2.424 \\
\hline
\end{tabular}

a. Predictors: (Constant), Motivasi (X2)

Berdasarkan hasil pengujian diperoleh nilai determinasi sebesar 0,516 artinya motivasi memiliki kontribusi pengaruh sebesar 51,6\% terhadap produktiivitas kerja karyawan.

Tabel Hasil Pengujian Koefisien Determinasi Pelatihan dan Motivasi Terhadap Produktiivitas kerja karyawan.

Model Summary

\begin{tabular}{ll|lcc} 
Model & $\mathrm{R}$ & R Square & Square & $\begin{array}{c}\text { Adjusted } \\
\text { Rtd. Error of the } \\
\text { Estimate }\end{array}$ \\
\hline 1 & $.777 \mathrm{a}$ & .604 & .591 & 2.211 \\
\hline
\end{tabular}

a. Predictors: (Constant), Motivasi (X2), Pelatihan (X1)

Berdasarkan hasil pengujian diperoleh nilai determinasi sebesar 0,604 artinya pelatihan dan motivasi secara simultan memiliki kontribusi pengaruh sebesar 60,4\% terhadap produktivitas kerja karyawan, sedangkan sisanya sebesar 39,6\% dipengaruhi faktor lain. 


\section{Uji Hipotesis}

Uji hipotesis Parsial (Uji t)

Pengujian hipotesis dengan uji t digunakan untuk mengetahui hipotesis parsial mana yang diterima.

Hipotesis pertama: Terdapat pengaruh yang signifikan antara pelatihan terhadap produktiivitas kerja karyawan.

Tabel Hasil Uji Hipotesis Pelatihan Terhadap Produktiivitas kerja karyawan.

Coefficientsa

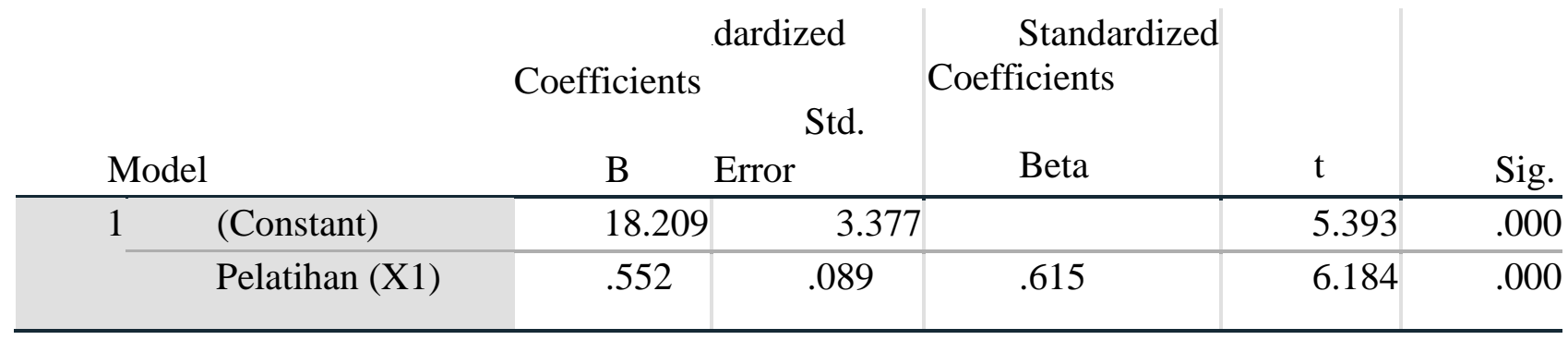

a. Dependent Variable: Produktiivitas kerja karyawan (Y)

Berdasarkan hasil pengujian pada tabel di atas, diperoleh nilai t hitung $>\mathrm{t}$ tabel atau $(6,184>1,998)$, dengan demikian hipotesis pertama yang diajukan bahwa terdapat pengaruh yang signifikan atara pelatihan terhadap produktiivitas kerja karyawan diterima.

Tabel Hasil Uji Hipotesis Motivasi Terhadap Produktiivitas kerja karyawan.

Coefficientsa

Model

Unstandardized Standardized

\begin{tabular}{|c|c|c|c|c|c|c|}
\hline \multirow{3}{*}{\multicolumn{2}{|c|}{ Model }} & \multicolumn{2}{|c|}{ Coefficients Coefficients t Sig. } & \multirow[b]{3}{*}{ Beta } & & \\
\hline & & & Std. & & & \\
\hline & & B & Error & & & \\
\hline 1 & (Constant) & 12.147 & \multicolumn{2}{|l|}{3.287} & 3.695 & .000 \\
\hline & Motivasi (X2) & .694 & .085 & .718 & 8.199 & .000 \\
\hline
\end{tabular}

a. Dependent Variable: Produktiivitas kerja karyawan (Y)

Berdasarkan hasil pengujian pada tabel di atas, diperoleh nilai t hitung $>\mathrm{t}$ tabel atau $(8,199>$ 1,998), dengan demikian hipotesis kedua yang diajukan bahwa terdapat pengaruh yang signifikan atara motivasi terhadap produktiivitas kerja karyawan diterima.

Uji Hipotesis Simultan (Uji F)

Pengujian hipotesis dengan uji $\mathrm{F}$ digunakan untuk mengetahui hipotesis simultan yang mana yang diterima.

Hipotesis ketiga Terdapat pengaruh yang signifikan antara pelatihan dan motivasi terhadap produktiivitas kerja karyawan.

Tabel Hasil Uji Hipotesis Pelatihan dan Motivasi Terhadap Produktiivitas kerja karyawan.

ANOVAa 


\begin{tabular}{|c|c|c|c|c|c|c|}
\hline Model & & $\begin{array}{l}\text { Sum } \\
\text { Squares } \\
\end{array}$ & $\mathrm{df}$ & $\begin{array}{l}\text { Mean } \\
\text { Square } \\
\end{array}$ & $\mathrm{F}$ & Sig. \\
\hline \multirow[t]{3}{*}{1} & Regression & 462.022 & 2 & 231.011 & 47.275 & $.000 \mathrm{~b}$ \\
\hline & Residual & 302.963 & 62 & 4.886 & & \\
\hline & Total & 764.985 & 64 & & & \\
\hline
\end{tabular}

Berdasarkan hasil pengujian pada tabel di atas, diperoleh nilai $\mathrm{F}$ hitung $>\mathrm{F}$ tabel atau $(47,275$ $>2,750$ ), dengan demikian hipotesis ketiga yang diajukan bahwa terdapat pengaruh yang signifikan atara pelatihan dan motivasi terhadap produktiivitas kerja karyawan diterima.

\subsection{Pembahasan}

\section{Pengaruh Pelatihan Terhadap Produktiivitas kerja karyawan}

Pelatihan berpengaruh signifikan terhadap produktiivitas kerja karyawan dengan korelasi sebesar 0,615 atau memiliki hubungan yang kuat dengan kontribusi pengaruh sebesar 37,8\%. Pengujian hipotesis diperoleh nilai thitung $>\mathrm{t}$ tabel atau $(6,184>1,998)$. Dengan demikian hipotesis pertama yang diajukan bahwa terdapat berpengaruh signifikan antara pelatihan terhadap produktiivitas kerja karyawan diterima.

\section{Pengaruh Motivasi Terhadap Produktiivitas kerja karyawan}

Motivasi berpengaruh signifikan terhadap produktiivitas kerja karyawan dengan korelasi sebesar 0,718 atau memiliki hubungan yang kuat dengan kontribusi pengaruh sebesar 51,6\%. Pengujian hipotesis diperoleh nilai $t$ hitung $>t$ tabel atau $(8,199>1,998)$. Dengan demikian hipotesis kedua yang diajukan bahwa terdapat berpengaruh signifikan antara motivasi terhadap produktiivitas kerja karyawan diterima.

\section{Pengaruh Pelatihan dan Motivasi Terhadap Produktiivitas kerja karyawan}

Pelatihan dan motivasi berpengaruh signifikan terhadap produktiivitas kerja karyawan dengan diperoleh persamaan regresi $\mathrm{Y}=6,954+0,307 \mathrm{X} 1+0,530 \mathrm{X} 2$, nilai korelasi sebesar 0,777 atau memiliki hubungan yang kuat dengan kontribusi pengaruh sebesar 60,4\% sedangkan sisanya sebesar 39,6\% dipengaruhi faktor lain. Pengujian hipotesis diperoleh nilai $\mathrm{F}$ hitung $>\mathrm{F}$ tabel atau $(47,275>$ 2,750). Dengan demikian hipotesis ketiga yang diajukan bahwa terdapat berpengaruh signifikan antara pelatihan dan motivasi terhadap produktiivitas kerja karyawan diterima.

\section{KESIMPULAN}

\subsection{Kesimpulan}

a. Pelatihan berpengaruh signifikan terhadap produktiivitas kerja karyawan dengan kontribusi pengaruh sebesar 37,8\%. Uji hipotesis diperoleh nilai t hitung $>t$ tabel atau $(6,184>1,998)$.

b. Motivasi berpengaruh signifikan terhadap produktiivitas kerja karyawan dengan kontribusi pengaruh sebesar 51,6\%. Uji hipotesis diperoleh nilai t hitung $>\mathrm{t}$ tabel atau $(8,199>1,998)$.

c. Pelatihan dan motivasi berpengaruh signifikan terhadap produktiivitas kerja karyawan dengan kontribusi pengaruh sebesar 60,4\% sedangkan sisanya sebesar 39,6\% dipengaruhi faktor lain. Uji hipotesis diperoleh nilai $\mathrm{F}$ hitung $>\mathrm{F}$ tabel atau $(47,275>2,750)$.

\subsection{Saran}

a. PT Lion Mentari Airlines perlu meningkatkan Program Quality Control terhadap pelatihan karyawan sesuai dengan keperluan/requirements masing-masing divisi sehingga karyawan 
mampu berbuat lebih banyak dan lebih memahami tugas dan tanggung jawab sesuai dengan SOP yang berlaku.

b. PT Lion Mentari Airlines perlu membedah materi pelatihan secara berkala untuk menyesuaikan terdahadap regulasi dan tekhnologi yang semakin berkembang.

c. PT Lion Mentari Airlines perlu memberikan motivasi dengan pengukuran yang seimbang berupa material maupun non-material terhadap karyawan sehingga dapat memberikan dorongan dan semangat kerja.

d. PT Lion Mentari Airlines perlu mengadakan kegiatan yang dapat mempersolid seluruh karyawan sehingga dapat menumbuhkan rasa cinta karyawan kepada perusahaan dan lingkungannya.

e. PT Lion Mentari Airlines perlu menganalisa kembali mengenai input dan output yang belum seimbang sehingga produktivitas kerja masing- masing karyawan tidak seimbang pula.

f. PT Lion Mentari Airlines perlu meningkatkan produktivitas kerja melalui lingkaran pengawasan mutu (Quality Control Circles) serta didukung oleh pelatihan yang akan memberikan karyawan kepercayaan diri yang tinggi serta motivasi sebagai dorongan proses mencapaian tujuan perusahaan.

\section{DAFTAR PUSTAKA}

Algifari. (2015). “Analisis Regresi untuk Bisnis dan Ekonomi”. Yogyakarta: BPFE.

Arikunto, Suharsimi (2014). “Prosedur Penelitian Suatu Pendekatan Praktek”. Jakarta: Rineka Cipta.

Cahyono, Y., Jihadi, . M., Arifin, . Z., Purnamasari, . W., Musnaini, ., Wijoyo, . H., Fitriaty, ., Putra,

R. S., Putri, . R. A., Muliansyah, . D., Suryani, . P. \& Purwanto, . A. (2020) Do Servant Leadership Influence Market Performance? Evidence from Indonesian Pharmacy Industries. Systematic Reviews in Pharmacy, 11 (9), 439-451. doi:10.31838/srp.2020.9.62

Dessler, Gary. (2010). Manajemen Sumbaer Daya Manusia “Edisi Kesepuluh”. Jakarta: Indeks.

Effendy, A., \& Sunarsi, D. (2020). Persepsi Mahasiswa Terhadap Kemampuan Dalam Mendirikan UMKM Dan Efektivitas Promosi Melalui Online Di Kota Tangerang Selatan. Jurnal Ilmiah MEA (Manajemen, Ekonomi, \& Akuntansi), 4(3), 702-714. https://doi.org/10.31955/mea.vol4.iss3.pp702-714

Fahmi, K., Kurniawan, T., Cahyono, Y., \& Sena, A. (2020). Did Servant, Digital and Green Leadership Influence Market Performance? Evidence from Indonesian Pharmaceutical Industry. Systematic Reviews in Pharmacy, 11(9), 642-653.

Gomes, Faustion. (2003). Manajemen Sumbaer Daya Manusia. Yogyakarta: Andi Offset.

Gorda, IGN. (2004). Manajemen Sumbaer Daya Manusia. Singaraja: Penerbit STIE Satya Dharma.

Handoko, Tani. (2003). Manajemen Personalia Dan Sumber Daya Manusia. Yogyakarta: BPFE.

Hasibuan, Malayu. (2001). Manajemen Sumber Daya Manusia "EdisiRevisi” Jakarta: Bumi Aksara.

Imam Ghozali (2017). “Aplikasi Analisis Multivariate Dengan Program SPSS”. Edisi Kelima. Semarang: Badan Penerbit Undip.

Istijanto (2014) “Riset Sumber Daya Manusia”. Jakarta: PT. Gramedia Pustaka 
Muhidin, S. A dan Abdurrahman, M. (2007) Analisis Korelasi, Regresi dan Jalur dalam Penelitian. Jakarta: Pustaka Setia.

Notoatmojo, Soekidjo. (2015). Pengembangan Sumber Daya Manusia. Jakarta: Rineka Cipta.

Prasada, D., Sunarsi, D., \& Teriyan, A. (2020). Pengaruh Etos Kerja Dan Kompensasi Terhadap Komitmen Organisasi Pada DHL Logistic Di Jakarta. JENIUS (Jurnal Ilmiah Manajemen Sumber Daya Manusia), 4(1), 51-60.

Rifuddin, B., Ilham, D., \& K, N. (2020). Academic Services in Islamic Education Management Study Program: The Actualization of the Basic Values of the State Civil Apparatus at IAIN Palopo. International Journal of Asian Education, 1(2), 81-94. https://doi.org/10.46966/ijae.v1i2.34

Rivai, Veithzal. (2014). Pelatihan Kerja Karyawan "EdisiRevisi”. Jakarta.

Sedarmayanti. (2009). Sumber Daya Manusia dan Produktivitas Kerja. Bandung: Mandar Maju.

Siagian, . A. O., Nufus, . K., Yusuf, . N., Supratikta, . H., Maddinsyah, . A., Muchtar, . A., Sari, . W. I., Sunarsi, . D., Akbar, . I. R., Arianto, . N., Purwanto, . A., Noryani, . \& Wijoyo, . H. (2020) A Systematic Literature Review of Education Financing Model in Indonesian

School. Systematic Reviews in Pharmacy, 11 (10), 638-644. doi:10.31838/srp.2020.10.96

Siagian, Sondang. (2015). Manajemen Sumber Daya Manusia. Bandung: Bumi Askara.

Sinulingga, S. (2012). Metode Penelitian Edisi 2, Medan: USU Press.

Sugiyono. (2010). Metode Penelitian Kuantitatif dan R\&D. Bandung: Alfabeta.

Sunarsi, D. (2018). Buku Ajar: Seminar Perencanaan Sumber Daya Manusia. Tangerang Selatan: Asmoro Mediatama

Sunarsi, D. (2019). Penerapan MSDM Strategis Dalam Upaya Meningkatkan Kemampuan Organisasi dalam menyongsong Revolusi 4.0. Jurnal Ilmiah MEA (Manajemen, Ekonomi, \& Akuntansi), 3(1), 221-233. https://doi.org/10.31955/mea.vol3.iss1.pp221-233

Sunarsi, D., Wijoyo, H., Prasada, D., \& Andi, D. (2020, September). Pengaruh Lingkungan Kerja Terhadap Kinerja Karyawan Pada PT. Mentari Persada Di Jakarta. In Seminar Nasional Manajemen, Ekonomi, Akuntansi (Vol. 5, No. 1, pp. 117-123).

Supriyadi, D., Syafitri, . L. N. H., Widodo, S. F. A., Wahidi, R., Arinta, . Y. N., Nabhan, . F., Mufid, A., Purwanto, . A., Fahlevi, . M., Sunarsi, . D. \& Cahyono, . Y. (2020) Innovation And Authentic Leadership Of Islamic University Lectures In Faculty Pharmacy Faculty: What Is The Role Of Psychological Capital?. Systematic Reviews in Pharmacy, 11 (8), 383-393. doi:10.31838/srp.2020.8.56 